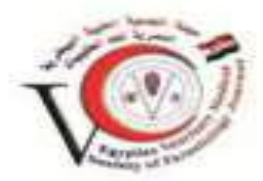

Original Article

\section{Evaluation of Poly lactide-co-glycolide Acid [PLGA] Nanoparticles Loaded with Praziquantel in treatment of experimental murine Schistosomiasis mansoni.}

\section{Gamal A. Abo Sheishaa ${ }^{*}$, Mostafa El Shahat Mostafa ${ }^{1 * *}$, Ibrahim R. Aly Shalash 2, Rabab S. Hamad ${ }^{3}$ \\ Departments of Medical Parasitology, Faculties of Medicine, (Cairo* and Damietta**), Al-Azhar University ${ }^{1}$ and Theodor Bilharz Research Institute 2,3, Imbaba, Giza, Egypt, parasitology, parasitic immunology and evaluation of drugs ${ }^{2}$, Department of Biological Sciences, King Faisal University ${ }^{3}$, Saudi Arabia . (Correspondence: Gamal A. Abo Sheishaa, e-mail: drgamalali912@gmail.com)}

\section{ABSTRACT}

Background: Schistosomiasis is a prevailing disease, reported globally in many countries. The classical treatment, although effective, had many disadvantages. Thus, there is a recent interest in nanoparticles [NPs] as a vehicle to increase drug effectiveness and reduce side effects.

Aim of the work: The current study was designed to evaluate the in vivo antischistosomal effects of praziquantel-loaded PLGA NPs compared to praziquantel [PZQ] in treatment of experimental murine Schistosomiasis mansoni as regards of worm burden, oogram pattern, tissue egg load, liver enzymes status [AST and ALT], cytokines changes [Interleukin 4(IL-4), Interleukin 10 (IL-10) and Interferon-gamma (IFN-y)], Interleukin 4 [LL-4] and Interleukin $10 \mathrm{IFN}-\gamma]$, and histopathological studies [granulomas number and diameter].

Materials and Methods: Eighty mice were classified into eight groups [10 mice each]: normal control, S.mansoni infected untreated mice [infected control], infected mice treated with unloaded PLGA NPs on the $14^{\text {th }}$ day post infection [PI], infected mice treated with unloaded PLGA NPs on the $42^{\text {nd }}$ day PI, infected mice treated with PZQ on the $14^{\text {th }}$ day $\mathrm{Pl}$, infected mice treated with $\mathrm{PZQ}$ on the $42^{\text {nd }}$ day $\mathrm{PI}$, infected mice treated with PZQ-loaded PLGA NPs on the 14th day PI and infected mice treated with PZQ-loaded PLGA NPs on the $42^{\text {nd }}$ day PI. All mice were sacrificed ten weeks PI.

Results: Treated group with PZQ alone on the $42^{\text {nd }}$ day PI showed a significant reduction in total worm burden, reduction in tissue egg count, increase in serum IL-10 level, decrease in serum AST, ALT, IL-4 and IFN-y levels and reduction in mean hepatic granulomas diameter and number when compared to infected control group. These results were improved when PZQ loaded on PLGA NPs was gevin on the 42nd day PI showed by no detection of immature ova, a highly significant reduction in the total worm burden in comparison to infected control group. The reduction in mean hepatic granulomas diameter and number and tissue egg count in late PZQ-loaded PLGA NPs group was higher than late $P Z Q$ group. While the treated groups with PZQ alone, or loaded on PLGA NPs on the 14th day PI and group treated with unloaded PLGA NPs on the $14^{\text {th }}$ day PI showed non-significant difference regarding total worm burden, tissue egg count, mean hepatic granulomas diameter and number and serum levels of ALT, AST, IL-4, and IL-10 compared to infected control group.

Conclusion: PLGA NPs improved the anti-schistosomal effects of PZQ regarding all assessed parameters, especially a highly significant reduction in mean hepatic granulomas diameter and number by its actions through upregulation of proinflammatory cytokines.

Keywords: Poly [lactide-co-glycolide]; Nanoparticles; Schistosoma mansoni; Loading; Efficacy of drug. 


\section{INTRODUCTION}

Human schistosomiasis, one of the most prevalent neglected tropical diseases, is a major public health problem affecting more than 200 million people in 78 countries and $~ 800$ million people are at risk of infection (Grimes et al., 2015). It is a helminthic disease caused by intravascular trematode of the Schistosoma genus, with three main species adapted to human infection: Schistosoma mansoni, $S$. haematobium, and $S$. japonicum. Poor sanitary conditions and low economic development are involved in the disease dissemination (Rollinson et al., 2013). Schistosomiasis was recognized by WHO, as the $2^{\text {nd }}$ most important disease, surpassed only by malaria. Thus, schistosomiasis control remains a challenge in endemic regions (Inobaya et al., 2014). Egypt has been plagued by Schistosomiasis and it was traditionally the most important public health concern. Treatment of schistosomiasis serves three purposes: reversing acute disease, prevention of complications, and neuroschistosomiasis (Bahgat, 2014).The treatment of choice is praziquantel. This drug has the advantage of low cost and wide therapeutic spectrum by operating in adult forms of all species of Schistosomes. On the contrary, it does not exert any effective action on immature worms, due to the fast metabolism of praziquantel after oral intake. The drug is converted to an inactive or less potent metabolite (Liu et al., 2017). Also, the presence of younger forms in the systemic circulation, leads to the reduction of exposure to praziquantel. So, it is necessary that, high oral doses are needed to overcome first-pass metabolism and achieve sufficient drug concentrations in the larval tissue. Furthermore, the low solubility and bioavailability of praziquantel lead to limitation of its use. Thus, many trials had described different technological substitutes to improve the oral absorption of this drug and used new compounds in the prevention and treatment of this disease
(De Souza et al., 2014).

Due to its poor solubility in water, low oral bioavailability, and risk of development of resistance to praziquantel, it would be essentil to develop a novel product that can overcome these shortcomings by making praziquantel an excellent candidate for encapsulation in solid lipid nanoparticles (Pérez del Villar., 2012). PLGA NPS have the advantages of different colloidal carriers and also avoid some of their disadvantages (Sun et al., 2019).

This study was aims to evaluate the in vivo anti-schistosomal effects of PZQ-loaded PLGA NPs compared to $P Z Q$ alone in treatment of experimental murine schistosomiasis mansoni regarding the following parameters: parasitological parameters [worm burden, oogram pattern and tissue egg load], biochemical parameters [AST, and ALT], immunological parameters $[\mathrm{LL}-4, \quad \mathrm{IL}-10$ and IFN-y,], and histopathological parameters [granulomas number and diameter].

\section{MATERIAL AND METHODS:}

The study was held at the Biological Supply Program Unit for Schistosoma mansoni inTheodor Bilharz Research Institute [SBSP/TBRI] Giza, Egypt, in firm agreement with the TBRI ethical guidelines for use of animals in research. This study was conducted on eighty laboratory Swiss albino female mice 6-8 weeks old. They were clean from parasitic infection, weighed $20 \pm 2 \mathrm{~g}$ at the beginning of the experiment. Animals were housed in conditioned rooms with a stable temperature at $21^{\circ} \mathrm{C}$, with free access to sterile water ad libitum, and fed a balanced diet with $14 \%$ protein.

\section{S. mansoni cercariae}

S.mansoni cercariae were obtained from infected Biomphalaria alexandrina snails reared and maintained at SBSP/TBRI. Mice were infected subcutaneously with freshly emerged cercariae in dose of $80 \pm 10$ S.mansoni cercariae/mouse according to the (Peters and 
Warren, 1969).

Preparation of PLGA Nanoparticles:

PLGA; Poly (D,L-lactide-co-glycolide) [50:50, $M_{w}$. 17000] [Sun Pharma, Vadodara]. Dichloromethane [DCM], acetone, polyvinyl alcohol [PVA], Triton X-100, dialysis membrane [MWCO 6,000 -7,000 Da] were purchased from Himedia, Mumbai, India. All solvents and reagents used were of analytical grade unless stated otherwise. Double distilled water [DDW] was used in the study.

\section{Method of preparation:}

Empty NPs were prepared by the double emulsion-solvent evaporation technique. PLGA was dissolved in a mixture of dichloromethane [DCM] and acetone then polyvinyl alcohol [PVA] solution was added. Further mixture was emulsified by sonication for 60 seconds in an ice bath and water-in-oil [w/o] emulsion was formed. Again PVA solution was added and sonicated for 60 seconds in an ice bath and water-in-oil-in-water [w/o/w] emulsion was formed. This resulting water-in-oil-in-water [w/o/w] emulsion was again diluted with $20 \mathrm{ml}$ of PVA solution and slow speed stirring was continued for 5 hours to facilitate evaporation of the solvent. The NPs so formed were collected, washed, and freeze-dried (Chitkara and Kumar, 2013).

\section{Praziquantel:}

Biltricide, [Alexandria Co. for Pharmaceuticals and Chemical Industries] is available as tablets and each tablet contains 600 $\mathrm{mg}$ of $\mathrm{PZQ}$ (active ingredient). PZQ was given to mice orally in the form of an aqueous suspension in $2 \%$ Cremophore-El solution (Sigma-Aldrich Chemical Co, St. Louis, MO, USA) freshly prepared immediately prior to administration to the mice by gastric gavage in a dose of 500 $\mathrm{mg} / \mathrm{kg} /$ day (Gonnert and Andrews, 1977).

\section{Preparation of PZQ-loaded nanoparticles:}

The drug was loaded at the initial step of NPs preparation. The drug was dissolved in 1.5\% PVA solution, and then was added to the dissolved PLGA solution by syringe and further steps were followed as in the case of unloaded NPs.

\section{Study design:}

Eighty female Swiss albino mice were clasified into eight groups [10 mice/group] as follows:

- Group 1: Normal control received a normal diet.

- Group 2: Infected mice with S.mansoni and received a normal diet [infected control ].

- Group 3: Infected mice with S.mansoni then received a single dose of unloaded PLGA NPs [50 $\mu \mathrm{g} / \mathrm{kg}$ ] on the $14^{\text {th }}$ day PI. [Early PLGA NPs -treated group].

- Group 4: Infected mice with S.mansoni then received a single dose of unloaded PLGA NPS on the $42^{\text {nd }}$ day PI. [Late PLGA NPs -treated group].

- Group 5: Infected mice with S.mansoni then received a single dose of $P Z Q$ on the $14^{\text {th }}$ day PI. [Early PZQ-treated group].

- Group 6: Infected mice with S.mansoni then received a single dose of $P Z Q$ on the $42^{\text {nd }}$ day $\mathrm{PI}$. [Late PZQ-treated group].

- Group 7: Infected mice with S.mansoni then received a single dose of PLGA NPs loaded with $P Z Q$ on the $14^{\text {th }}$ day PI. [Early PZQloaded PLGA NPs treated group].

- Group 8: Infected mice with S.mansoni then received a single dose of PZQ-loaded PLGA NPs on the $42^{\text {nd }}$ day PI. [Late PZQ-loaded PLGA NPs treated group].

All mice in different groups were deprived of food the night before treatment and they allowed to eat $1 \mathrm{~h}$ after treatment.

\section{Scarification:}

Mice of all experimental groups were 
sacrificed ten weeks PI by decapitation without anesthesia, and were subjected to the following investigations.

\section{Worm burden:}

Adult worms of S.mansoni were reaped from each sacrificed mouse by the perfusion of hepatic and portomesenteric vessels, and then the collected worms were counted (Duvall and De Witt, 1967). The reduction in numbers of worms post-treatment was calculated (Tendler et al., 1986).

\section{Tissue egg load in liver and intestine:}

The eggs number per one gram liver or intestinal tissue was detected by weighing a part of intestine or liver, then, it is digested and incubated in $5 \%$ potassium hydroxide overnight (Cheever, 1968). The eggs number per gram of intestinal or hepatic tissue were calculated by multiplying the average eggs number in each $1 \mathrm{ml}$ sample by the total volume of potassium hydroxide and then dividing that value by the sample weight.

\section{Oogram Patterns:}

The whole small intestine of each sacrificed mouse was removed, transferred to a petri dish and opened lengthwise into 3 parts (each $1 \mathrm{~cm}$ in length), and then squeezed between a standard glass slide and coverslip to identify and count various developmental stages of $S$. mansoni eggs [immature, mature and dead eggs] in the three samples from each mouse in each part, and the mean number of eggs of each developmental stage/animal was determined (Pellegrino et al.,1962).

\section{Histopathological study:}

Livers were removed from mice, washed by normal saline, fixed in $10 \%$ formalin and embedded in paraffin blocks. To measure granuloma, a $5 \mu \mathrm{m}$ thickness sections were cut by microtome, with a distance of $250 \mu \mathrm{m}$ apart to prevent re-measurement. Then, hematoxylin and eosin stains were used to stain sections. The counting of hepatic egg granulomas was achieved in five microscopic fields in serial tissue sections. The diameter of liver granulomas was measured by the ocular micrometer. The mean granuloma diameter was estimated by dividing the sum of perpendicular diameters (vertical and transverse diameters)/2. The granuloma size is expressed as the mean area measured in $\mu \mathrm{m} \pm \mathrm{SD}$. Only lobular granulomas (non-confluent) containing ova in their centers were measured (Von Lichtenberg, 1962).

\section{Serum preparation:}

For serological investigtions, blood samples from each mouse were collected through a small puncture of the caudal vein using a sterile needle. Samples were transferred to a $1.5 \mathrm{ml}$ tube, clotted, and then centrifuged for serum separation. Serum samples were kept at $-20^{\circ} \mathrm{C}$ until used.

\section{Assessment of serum liver enzymes:}

Serum alanine aminotransferase (ALT) and aspartate aminotransferase (AST) activities were analyzed using a commercial kit [Boehringer reagent kit, Mannheim, Germany] according to the manufacturer's instructions (Reitman and Frankel, 1957).

\section{Cytokine assays:}

Serum Interleukin 4 (IL-4), Interleukin 10(IL10) and Interferon-gamma (IFN- $\gamma$ ) concentrations were determined by the enzyme linked immunosorbent assays according to the manufacturer's instructions [BioSource International, Inc., Camarillo, California, USA]. for, IL- 4, IL-10 and IFN- $y$.

\section{Statistical analysis:}

Collected data were arranged, coded, tabulated and introduced to a PC using the Statistical Package for Social Science [SPSS] for windows version 18.0. Data were represented as 
the mean \pm standard deviation (SD). The analysis of variance [ANOVA] procedure was used to clarify statistically significant differences between the different studied groups. $P$ value was considered statistically significant when $\mathrm{P}<0.05$.

\section{RESULTS}

Worm burden: late PZQ-loaded PLGA NPs infected treated group demonstrated a highlly significant reduction in mean total worm burden followed by late PZQ treated group, while other infected treated groups showed non-significant differences in comparison to infected control group Table (1).

Oogram patterns: late PZQ-loaded PLGA NPs treated group showed the highest elevation of the percentage of dead ova (95.31\%) with complete disappearance of immature ova followed by late $P Z Q$ treated group in comparison to infected control group Table(2).

Hepatic tissue egg load: There was a reduction in ova count in hepatic tissue of the infected treated groups; late $P Z Q$ and late PZQloaded PLGA NPs when compared with infected control group. The reduction in hepatic tissue egg load in late PZQ and late PZQ-loaded PLGA NPs infected treated mice groups was $94.2 \%$ and $97.1 \%$ respectively, with a highly significant difference $(P<0.001)$, while other infected treated groups showed non-significant reduction in comparison to infected control group Table (2).

Intestinal tissue egg load: There was a reduction in ova count in intestinal tissue in late $P Z Q$ and late PZQ-loaded PLGA NPs in comparison with infected control group. The reduction in intestinal tissue egg count in late $P Z Q$ and late PZQ-loaded PLGA NPs infected treated mice groups was $95.8 \%$ and $98.1 \%$ respectively, with a highly significant difference $(P<0.001)$, while other infected treated groups showed nonsignificant reduction in comparison to infected control group Table(2).

\section{Biochemical Parameters:}

Liver enzymes: The measured levels of serum AST and ALT were found to be significantly increased in infected controls in comparison to normal controls. At the same time, treated groups with PZQ alone or loaded on PLGA NPs at the $42^{\text {nd }}$ day $\mathrm{PI}$ showed highly significant decrease in levels of AST and ALT in comparison to infected control group. The decrease in AST and ALT levels in late PZQ-loaded PLGA NPs infected treated group was higher than late $P Z Q$ treated group. While other infected treated groups showed non-significant decrease in comparison to infected control group Table(3).

Serum cytokines assay: The measured levels of cytokines (IL-4, IL-10 and IFN- $\gamma$ were found to be significantly increased in infected mice in comparison to normal controls. While the treated group with $\mathrm{PZQ}$ alone on the $42^{\text {nd }}$ day $\mathrm{PI}$ and treated group with PZQ-loaded PLGA NPs on the $42^{\text {nd }}$ day $\mathrm{PI}$ showed highly significant decrease in IL-4 level and highly significant increase in IL-10 level in comparison to infected controls. On the other hand, there was a significant decrease in IFN- $y$ levels was detected in all treated groups in comparison to infected control group Table(4).

Stained liver sections showed reduction in mean diameter of hepatic granulomas in late $P Z Q$ and late PZQ-loaded PLGA NPs treated groups was $(73.5 \%$ and $97.6 \%)$ respectively, with highly significant difference $(P<0.001)$ in comparison to infected control group. The reduction in mean granuloma number in late $P Z Q$ and late $P Z Q$ loaded PLGA NPs treated groups was $(76.1 \%$ and $90.3 \%$ ) respectively, with highly significant difference $[P<0.001]$ in comparison to infected control group. While other infected treated groups showed non-significant reduction in comparison to infected control group Table (5). 
Table(1): Effect of different treatment regimens on worm burden in Schistosoma mansoni infected mice in comparison to infected control group.

\begin{tabular}{|c|c|c|}
\hline Parameters & $\begin{array}{c}\text { Total worm burden } \\
\text { Mean } \pm \text { SD }(\mathbf{R} \%)\end{array}$ & P value \\
\hline Groups & $17.1 \pm 1.97$ & \\
\hline Early unloadeded PLGA NPs treated & $16.5 \pm 1.7(\mathrm{R} 3.51 \%)$ & $0.48(\mathrm{NS})$ \\
\hline Late unloaded PLGA NPs treated & $15.9 \pm 1.86(\mathrm{R} 7.01 \%)$ & $0.18(\mathrm{NS})$ \\
\hline Early PZQ treated & $16.2 \pm 1.22(\mathrm{R} 5.26 \%)$ & $0.24(\mathrm{NS})$ \\
\hline Late PZQ treated & $4.8 \pm 1.74(\mathrm{R} 71.92 \%)$ & $<0.01^{*}$ \\
\hline Early PZQ-loaded PLGA NPs treated & $15.8 \pm 1.46(\mathrm{R} 7.60 \%)$ & $0.11(\mathrm{NS})$ \\
\hline Late PZQ-loaded PLGA NPs treated & $1.3 \pm 1.26(\mathrm{R} 92.39 \%)$ & $<0.001^{\text {** }}$ \\
\hline
\end{tabular}

(NS): Non-significant, (SD): Standard deviation, (R\%): percent of reduction, *significant, **highly significant

Table (2): Effect of different treatment regimens on oogram patterns and ova count in tissues in Schistosoma mansoni infected mice in comparison to infected control group.

\begin{tabular}{|c|c|c|c|c|c|c|c|}
\hline \multirow[b]{3}{*}{ Groups } & \multicolumn{3}{|c|}{$\begin{array}{l}\text { Oogram patterns (\% of ova } \\
\text { developmental stages) }\end{array}$} & \multicolumn{4}{|c|}{ Tissue egg load (R\%) } \\
\hline & \multirow{2}{*}{ Immature } & \multirow{2}{*}{ Mature } & \multirow{2}{*}{ Dead } & \multicolumn{2}{|l|}{ Liver } & \multicolumn{2}{|c|}{ Intestine } \\
\hline & & & & Mean \pm SD & $P$ value & Mean \pm SD & $P$ value \\
\hline Infected control & 50.6 & 42.33 & 7.07 & $8995.2 \pm 1201.75$ & - & $12485.8 \pm-3741$ & - \\
\hline $\begin{array}{c}\text { Early unloaded } \\
\text { PLGA NPs treated }\end{array}$ & 45.31 & 45.43 & 9.26 & $\begin{array}{l}8959.2 \pm 1338.1 \\
(R 0.4 \%)\end{array}$ & 0.95 & $\begin{array}{c}12448.3 \pm 612.19 \\
\text { (R 0.3\%) }\end{array}$ & 0.98 \\
\hline $\begin{array}{c}\text { Late unloaded } \\
\text { PLGA NPs treated }\end{array}$ & 44.56 & $\begin{array}{c}43.23 \\
\%\end{array}$ & 12.21 & $\begin{array}{l}8860.3 \pm 1201.3 \\
(\mathrm{R} 1.5 \%)\end{array}$ & 0.80 & $\begin{array}{c}12432.3 \pm 1236.28 \\
(R 0.4 \%)\end{array}$ & 0.97 \\
\hline Early $P Z Q$ treated & 41.31 & 46.11 & 12.58 & $\begin{array}{c}8735.9 \pm 901.1 \\
\text { (R 2.9\%) }\end{array}$ & 0.59 & $\begin{array}{c}11789.6 \pm 1189.1 \\
\text { (R 5.6\%) }\end{array}$ & 0.58 \\
\hline Late $P Z Q$ treated & 2.38 & 4.53 & 93.09 & $\begin{array}{c}521.7 \pm 29.54 \\
(\mathrm{R} 94.2 \%) \\
\end{array}$ & $<0.001^{* *}$ & $\begin{array}{c}524.4 \pm 705.52 \\
(\mathrm{R} 95.8 \%) \\
\end{array}$ & $<0.001^{* *}$ \\
\hline $\begin{array}{l}\text { Early PZQ-loaded } \\
\text { PLGA NPs treated }\end{array}$ & 39.31 & 43.91 & 16.78 & $\begin{array}{c}8514.3 \pm 1313.3 \\
(\mathrm{R} 5.4 \%) \\
\end{array}$ & 0.4 & $\begin{array}{c}11624.3 \pm 703.05 \\
\text { (R 6.9\%) } \\
\end{array}$ & 0.48 \\
\hline $\begin{array}{l}\text { Late PZQ-loaded } \\
\text { PLGA NPs treated }\end{array}$ & $0 \%$ & 4.69 & 95.31 & $\begin{array}{c}260.3 \pm 12.89 \\
\text { (R } 97.1 \%)\end{array}$ & $<0.001^{* *}$ & $\begin{array}{c}237.3 \pm 12.36 \\
(\mathrm{R} 98.1 \%) \\
\end{array}$ & $<0.001^{* *}$ \\
\hline
\end{tabular}

Tables (3): Effect of different treatment regimens on liver enzymes activities of $S$. mansoni infected mice in comparison to infected control group.

\begin{tabular}{|c|c|c|c|c|}
\hline Groups Parameters & $\begin{array}{c}\text { ALT } \\
\text { Mean } \pm \text { SD }\end{array}$ & P value & $\begin{array}{c}\text { AST } \\
\text { Mean } \pm \text { SD }\end{array}$ & P value \\
\hline Normal control & $46.9 \pm 4.13$ & - & $42.9 \pm 2.86$ & - \\
\hline Infected control & $71.1 \pm 5.38$ & $<0.001^{* *}$ & $69.28 \pm 3.86$ & $<0.001^{* *}$ \\
\hline Early unloaded PLGA NPs treated & $68.95 \pm 8.93$ & 0.52 & $67.7 \pm 5.75$ & 0.48 \\
\hline Late unloaded PLGA NPs treated & $67.3 \pm 7.46$ & 0.21 & $66.9 \pm 6.22$ & 0.32 \\
\hline Early PZQ treated & $65.1 \pm 8.32$ & 0.07 & $64.88 \pm 8.99$ & 0.17 \\
\hline Late PZQ treated & $45.1 \pm 5.86$ & $<0.001^{* *}$ & $41.29 \pm 7.81$ & $<0.001^{* *}$ \\
\hline Early PZQ-loaded PLGA NPs treated & $66.0 \pm 8.32$ & 0.14 & $60.8 \pm 8.9$ & 0.21 \\
\hline Late PZQ-loaded PLGA NPs treated & $44.8 \pm 6.55$ & $<0.001^{* *}$ & $38.3 \pm 6.52$ & $<0.001^{* *}$ \\
\hline
\end{tabular}


Table (4): Effect of different treatment regimens on level of serum IL-4, IL-10 and IFN- $y$ of S. mansoni infected mice in comparison to infected control group.

\begin{tabular}{|c|c|c|c|c|c|c|}
\hline Parameters & $\begin{array}{c}\mathrm{IL}-4 \mathrm{Pg} / \mathrm{ml} \\
\text { Mean } \pm \text { SD } \\
\text { Animal groups }\end{array}$ & P value & $\begin{array}{c}\mathrm{IL}-10 \mathrm{Pg} / \mathrm{ml} \\
\text { Mean } \pm \text { SD }\end{array}$ & P value & $\begin{array}{c}\mathrm{IFN}-\mathrm{Pg} / \mathrm{ml} \\
\text { Mean } \pm \text { SD }\end{array}$ & P value \\
\hline Normal control & $14.39 \pm 0.68$ & & $213.8 \pm 30.89$ & - & $229.8 \pm 29.3$ & \\
\hline $\begin{array}{c}\text { Infected control } \\
\begin{array}{c}\text { Early unloaded PLGA } \\
\text { NPs treated }\end{array}\end{array}$ & $61.19 \pm 13.12$ & 0.12 & $511.5 \pm 45.56$ & 0.86 & $503.13 \pm 21.91$ & $<0.001^{* *}$ \\
\hline $\begin{array}{c}\text { Late unloaded PLGA } \\
\text { NPs treated }\end{array}$ & $59.9 \pm 12.51$ & 0.07 & $513.8 \pm 46.53$ & 0.76 & $430.26 \pm 45.9$ & $<0.001^{* *}$ \\
\hline Early PZQ treated & $60.8 \pm 10.21$ & 0.7 & $516.6 \pm 50.35$ & 0.58 & $480.1 \pm 32.1$ & $<0.001^{* *}$ \\
\hline Late PZQ treated & $46.4 \pm 8.62$ & $<0.001^{* *}$ & $578.4 \pm 21.91$ & $<0.001^{* *}$ & $616.51 \pm 31.3$ & $0.007^{* *}$ \\
\hline $\begin{array}{c}\text { Early PZQ-loaded } \\
\text { PLGA NPs treated }\end{array}$ & $61.1 \pm 13.1$ & 0.12 & $517.3 \pm 41.51$ & $<0.58$ & $520.32 \pm 41.21$ & $<0.001^{* *}$ \\
\hline $\begin{array}{c}\text { Late PZQ-loaded PLGA } \\
\text { NPs treated }\end{array}$ & $21.63 \pm 5.9$ & $<0.001^{* *}$ & $585.9 \pm 36.32$ & $<0.001^{* *}$ & $622.65 \pm 24.32$ & $0.009^{* *}$ \\
\hline
\end{tabular}

Table (5): Effect of different treatment regimens on mean hepatic granulomas diameter and number of of $S$. mansoni infected mice in comparison to infected control group.

\begin{tabular}{|c|c|c|c|c|}
\hline \multirow{2}{*}{$\begin{array}{l}\text { Parameters } \\
\text { Animal groups }\end{array}$} & \multicolumn{2}{|c|}{ Granuloma diameter } & \multicolumn{2}{|c|}{ Granuloma number } \\
\hline & Mean士 SD ( R \%) & $P$ value & Mean \pm SD (R\%) & $P$ value \\
\hline Infected control & $331 \pm 78.5$ & - & $11.3 \pm 2.5$ & - \\
\hline $\begin{array}{c}\text { Early unloaded PLGA NPs } \\
\text { treated }\end{array}$ & $316 \pm 87.2(\mathrm{R} 4.5 \%)$ & 0.69 & $10.7 \pm 2.6($ R $5.3 \%)$ & 0.61 \\
\hline $\begin{array}{l}\text { Late unloaded PLGA NPS } \\
\text { treated }\end{array}$ & $301.2 \pm 74.9$ (R 9\%) & 0.4 & $9.8 \pm 2.3(\mathrm{R} \mathrm{13.3 \% )}$ & 0.18 \\
\hline Early PZQ treated & $287.5 \pm 75.6(\mathrm{R} 13.1 \%)$ & 0.22 & $10.7 \pm 1.9$ (R 5.3\%) & 0.55 \\
\hline Late $P Z Q$ treated & $87.7 \pm 5.1(\mathrm{R} 73.5 \%)$ & $<0.001$ & $2.7 \pm 0.9(\mathrm{R} 76.1 \%)$ & $<0.001$ \\
\hline $\begin{array}{l}\text { Early PZQ-loaded PLGA NPS } \\
\text { treated }\end{array}$ & $280.8 \pm 63.3(\mathrm{R} 15.2 \%)$ & 0.13 & $9.5 \pm 2.1(\mathrm{R} 15.9 \%)$ & 0.1 \\
\hline $\begin{array}{l}\text { Late PZQ-loaded PLGA NPs } \\
\text { treated }\end{array}$ & $7.8 \pm 0.9$ (R $97.6 \%)$ & $<0.001$ & $1.1 \pm 0.6(\mathrm{R} 90.3 \%)$ & $<0.001$ \\
\hline
\end{tabular}



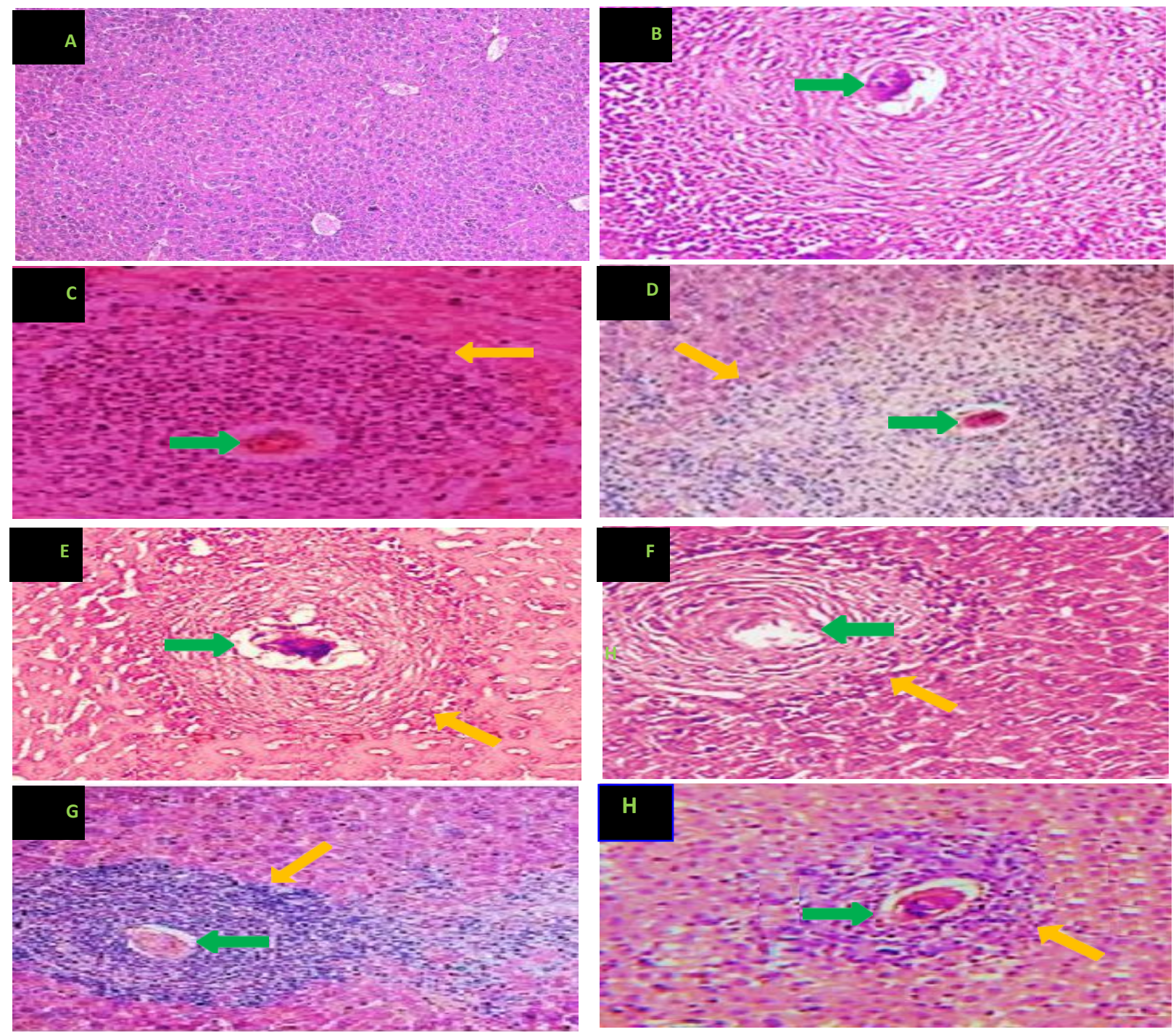
100).

Figure (1): Histopathological study of H\&E-stained liver sections of different groups of mice (X

[A] Normal control shows the normal architecture of hepatocytes which appears radiating from the central vein. The hepatocytes have an open face nucleus and acidophilic cytoplasm. Neither inflammatory cells nor granulomas are seen in the liver. [B] Infected control shows large granuloma of fibrocellular type. The egg is viable showing central miracidium. [C] Early unloaded PLGA NPs shows large granuloma of cellular types with dense epithelioid cells component and few lymphocytes with a viable egg. [D] Late unloaded PLGA NPs shows large granuloma of cellular types with dense epithelioid cells component and few lymphocytes. The egg is viable. [E] Early PZQ shows regressed granuloma markedly fibrosed with few epithelioid cells and few lymphocytes. The egg is partially degenerated. [F] Late PZQ shows resolved granuloma with marked fibrosis and few epithelioid cells and few lymphocytes. The egg is partially degenerated with moderate decrease in granuloma diameter. [G] Early PZQ-loaded PLGA NPs shows large granuloma of cellular types with dense lymphocyte component and few epithelioid cells. The egg is viable. [H] Late PZQ-loaded PLGA NPs shows small granuloma of fibrocellular types with few epithelioid cells and few lymphocytes. The egg is markedly degenerated with a marked decrease in granuloma diameter. 


\section{DISCUSSION}

Schistosomiasis, is a neglected tropical parasitic disease, it is endemic in 78 countries, that afflicts more than 240 million people (Santos et al., 2014). A vaccine for schistosomiasis is not yet present and chemotherapy depends on praziquantel which is very effective and safe. However, it is not devoid of disadvantages (e.g., stage-dependent susceptibility and poor efficacy against immature stages). Thus, there is a crucial need to search for new anti-schistosomal drugs. Recently, nanoparticles have gained more attention in the field of anti-parasitic medications (Yah and Sinate, 2015).

The anti-Schistosomal treatment was advocated as it delivers many supplementary goals, decrease egg-stimulated pathology, minimal changes of parenchyma with the eradication of worms (El-Lakkany et al., 2011).

The preceded researches concentrate on the epidemiological and physiological aspects of schistosomiasis. But, neglect the metabolic alterations evolved in the host as a sequelae of infection or medical PZQ) treatment. Thus, the evaluation of the treatment efficacy of nanoparticles loaded with $P Z Q$ in infected rats is important for the assessment of the infection extent and effectiveness of treatment. Measurement of different enzyme levels [e.g., serum AST and ALT] is largely used to assess liver cell damage caused by schistosomal infection (Aly and Mantawy, 2013).

In line with Mahmoud and Elbessouny (2013) study, the increase of serum levels of liver enzymes may be due to the damage of hepatocytes, due to parasite egg toxins effects. Furthermore, (Naik et al., 2011) reported that, damage of hepatocyte membrane looks to be the prime culprit for the significant increase in the serum enzymes, AST, ALT, and AFP after schistosomal infection.

The present work detected that the administration of PZQ-loaded PLGA NPs on the $42^{\text {nd }}$ day PI significantly reduced the total worm burden, tissue egg count and granulomas diameter and number. These results are in harmony with the study of (Rabia et al., 2010) who detected PZQ fatal effect on the worms, which may be due to metabolic effects, mechanical damage and muscular contraction of the worms subjected to treatment. (El- Moslemany et al., 2016) used a miltefosine encapsulation technique in LNCs in $S$. mansoni - infected mice. Their results revealed that, a single oral dose of encapsulated miltefosine led to decrease parasite load and reduce hepatic granulomas in infected mice. Similarly, (ElBeshbishi et al., 2013) reported that hepatic tissues of untreated-infected mice 6 weeks PI showed granulomata encircling recently deposited intact or partially degenerated ova with a mean number of $14.50 \pm 2.07$ and a diameter of $288.83 \pm$ $46.44 \mu \mathrm{m}$. However, in the PZQ group, the parenchymal changes were similar to those in the infected untreated controls, with the least reduction in the granuloma number and diameter of 36.55 and $22.34 \%$, respectively.

In our current study, the histopathological examination of the liver sections in late $P Z Q$ treated group revealed a reduction in the diameter of the liver granulomas in comparison with the infected control group in accordance with (EILakkany and Nosseir, 2007).

$P Z Q$ exert significant regulatory actions on responses of cell immune which increases CD8 cells and decreases CD4 $T$ cells, with the subsequent result of reduction in size of hepatic granuloma in schistosomiasis as described by (El- 
Ahwany et al., 2006).

Several studies revealed that $P Z Q$ is an effective medication to control infection with $S$. mansoni, stimulating a decrease in egg excretion and reversion of fibrosis in mice and humans (Martins-Leite et al., 2008). Probably, the increase in $T$ cell reactivity after treatment can be interpreted by the exposure of liberated antigens to the host immune system after the destruction of worms by drugs.

Moreover, the percentage of decrease in the egg count in the infected-treated groups was found to be high in the intestinal than in hepatic tissue. This difference was belonging to the excretion of some ova from the intestine prior to digestion and to the shift of worms to the liver after treatment (ElSayed et al., 2016).

In the current work, IL-4, and IL-10 displayed a highly significant increase in the infected control group in comparison with normal control group indicating that, immune reactions to schistosome in chronically infected patients are typically shifted toward Th2 cytokines. Also, IL-4 significantly decreased and IL-10 significantly increased in late $P Z Q$ and late PZQ-loaded PLGA NPs groups in comparison to infected control group. It has been suggested that IL-4 upregulates chemokine, fibroblast, collagen and matrix protein, which signify that this cytokine is a crucial cytokine for granuloma formation (Liu et al., 2002). This is agreed with that of (Franchimont et al., 1999) who demonstrated that administration of exogenous IL-10 resulted in a reduction of granuloma size. In addition, an opposite effect was seen in IL-10-deficient mice (Sanin et al., 2015). Nevertheless, type 2-related cytokines such as IL-4 and IL-10 impede classical activation of macrophage and has been involved in the formation of granulomas and fibrogenesis around eggs deposited in the tissues (Colley and Secor, 2014).

In the current study, there was significant difference in the IFN- $\gamma$ in the infected treated group than in the infected control group. This result was correlated with (Boros, 1994) who stated that IFN-y was found to be produced very early at the inception of the liver granulomatous response, by the time granulomas reached the maximal size, and at the same time, its production reduced. In addition, (Silva et al., 2004) supported and proposed that there was a significant general downregulation of responses of Th1cells in mice infected with Schistosoma. (Caldas et al., 2008) reached to the conclusion that, there was a mixed Th1 and Th2 cytokine expression during response in the acute phase, with a predominance of Th1 in the early infection. Also the excess production of IFN- $\gamma$, in the acute phase in comparison with chronic phase schistosomiasis, partially explained the lack of immune response modulation in the acute infections. All these responses may be due to an intense negative action of parasite eggs on schistosome antigen driven IFN-y production. Also, (Boros and Lukacs,1992) reported that IFN- $\gamma$ decreased the granulomas cellularity and reduced the size of granuloma in experimental schistosomiasis. These data are in line with (De Jesus et al., 2004) who proposed that IFN- $y$ is the principle Th1 cytokine included in the reduction of Th2 cells. It was reported that IFN-y plays a crucial role in the protective mechanism against periportal fibrosis (Kamdem et al., 2018).

In conclusion, PLGA NPs improved the antischistosomal effects of PZQ on adult Schistosoma mansoni, especially a highly significant reduction in number and diameter of hepatic granulomas by its action through upregulation of pro-inflammatory cytokines. 


\section{REFERENCES}

Aly HF, Mantawy MM., 2013. Efficiency of ginger [Zingbar officinale] against Schistosoma mansoni infection during host-parasite association. Parasitol Int. Aug;62[4]:380-9.

Bahgat MM., 2014. Interaction Between the Neglected Tropical Disease Human Schistosomiasis and HCV Infection in Egypt: a Puzzling Relationship. J Clin Transl Hepatol. Jun;2[2]:134-9.

Boros DL., 1994. The role of cytokines in the formation of the schistosome egg granuloma. Immunobiology. Oct;191[4-5]:441-50.

Boros DL, Lukacs NW., 1992. The role of egg antigens, cytokines in granuloma formation in murine schistosomiasis mansoni. Mem Inst Oswaldo Cruz. ;87 Suppl 4:75-9.

Colley DG, Secor WE., 2014. Immunology of human schistosomiasis. Parasite Immunol. Aug;36[8]:347-57.

Chitkara D, Kumar N., 2013. BSA-PLGA-based core-shell nanoparticles as carrier system for watersoluble drugs. Pharm Res. Sep;30[9]:2396-409.

Caldas IR, Campi-Azevedo AC, Oliveira LF, Silveira AM, Oliveira RC, Gazzinelli G., 2008. Human schistosomiasis mansoni: immune responses during acute and chronic phases of the infection. Acta Trop. Nov-Dec;108[2-3]:109-17.

Cheever AW., 1968. Conditions affecting the accuracy of potassium hydroxide digestion techniques for counting Schistosoma mansoni eggs in tissues. Bull World Health Organ. ;39[2]:328-31.

De Souza AL, Andreani T, de Oliveira RN, Kiill CP, dos Santos FK, Allegretti SM, Chaud MV, Souto EB, Silva AM, Gremião MP.,2014. In vitro evaluation of permeation, toxicity and effect of praziquantel-loaded solid lipid nanoparticles against
Schistosoma mansoni as a strategy to improve efficacy of the schistosomiasis treatment. Int $\mathrm{J}$ Pharm. Mar 10;463[1]:31-7.

De Jesus AR, Magalhães A, Miranda DG, Miranda RG, Araújo MI, de Jesus AA, Silva A, Santana LB, Pearce E, Carvalho EM., 2004. Association of type 2 cytokines with hepatic fibrosis in human Schistosoma mansoni infection. Infect Immun. Jun;72[6]:3391-7.

Duvall RH, DeWitt WB., 1967. An improved perfusion technique for recovering adult schistosomes from laboratory animals. Am J Trop Med Hyg. Jul;16[4]:483-6.

El-Moslemany RM, Eissa MM, Ramadan AA, ElKhordagui LK, El-Azzouni MZ., 2016. Miltefosine lipid nanocapsules: Intersection of drug repurposing and nanotechnology for single dose oral treatment of pre-patent schistosomiasis mansoni. Acta Trop. Jul;159:142-8.

El-Sayed NM, Fathy GM, Abdel-Rahman SA, ElShafei MA, 2016.. Cytokine patterns in experimental schistosomiasis mansoni infected mice treated with silymarin. J Parasit Dis. Sep;40[3]:922-9.

El-Beshbishi SN, Taman A, El-Malky M, Azab MS, El-Hawary AK, El-Tantawy DA., 2013. First insight into the effect of single oral dose therapy with artemisinin-naphthoquine phosphate combination in a mouse model of Schistosoma mansoni infection. Int J Parasitol. Jun;43[7]:521-30.

El-Lakkany NM, el-Din SH, Sabra AN, Hammam OA., 2011. Pharmacodynamics of mefloquine and praziquantel combination therapy in mice harbouring juvenile and adult Schistosoma mansoni. Mem Inst Oswaldo Cruz. Nov;106[7]:81422.

$\begin{array}{lllr}\text { El-Lakkany N, } & \text { Nosseir } & \text { M., } & 2007 . \\ \text { Pharmacodynamics } & \text { of pentoxifylline } & \text { and/or }\end{array}$ 
praziquantel in murine schistosomiasis mansoni. APMIS. Mar;115[3]:184-94.

El-Ahwany EG, Nosseir MM, Aly IR., 2006. Immunomodulation of pulmonary and hepatic granulomatous response in mice immunized with purified lung-stage schistosomulae antigen. J Egypt Soc Parasitol. Apr;36[1]:335-50.

Franchimont $D$, Martens $H$, Hagelstein MT, Louis E, Dewe W, Chrousos GP, Belaiche J, Geenen $\mathrm{V}, 1990$. Tumor necrosis factor alpha decreases, and interleukin-10 increases, the sensitivity of human monocytes to dexamethasone: potential regulation of the glucocorticoid receptor. J Clin Endocrinol Metab. Aug;84[8]:2834-9.

Grimes JE, Croll D, Harrison WE, Utzinger J, Freeman MC, Templeton MR.2015. The roles of water, sanitation and hygiene in reducing schistosomiasis: a review. Parasit Vectors. Mar 13:8:156.

Gonnert R., and Andrews P.,1977. Praziquantel, a new broad-spectrum antischistosomal agent. $Z$ Parasitenkd, ; 52:129-150.

Inobaya MT, Olveda RM, Chau TN, Olveda DU, Ross AG., 2014. Prevention and control of schistosomiasis: a current perspective. Res Rep Trop Med. Oct 17;[5]:65-75.

Kamdem SD, Moyou-Somo R, Brombacher F, Nono JK., 2018. Host Regulators of Liver Fibrosis During Human Schistosomiasis. Front Immunol. Nov 28;9:2781.

Liu LX, Li-Li J, Qiong C, Xiao-Lin F., 2017. Recent Advances in the Synthesis of Antischistosomal Drugs and Agents. Mini Rev Med Chem. ;17[5]:467-484.

Liu X, Kohyama T, Wang H, Zhu YK, Wen FQ, Kim HJ, Romberger DJ, Rennard SI, 2002. Th2 cytokine regulation of type I collagen gel contraction mediated by human lung mesenchymal cells. Am J
Physiol Lung Cell Mol Physiol. May;282[5]:L104956.

Mahmoud EA, Elbessouny AA., 2013. Effect of curcumin on hematological, biochemical and antioxidants parameters in Schistosoma mansoni infected mice. Int J Sci. ; 2 [1]: 1-- 14.

Martins-Leite P., Gazzinelli G., Alves-Oliveira L.F., Gazzinelli A., Malaquias L.C., CorreaOliveira R., Teixeira-Carvalho A., and Silveira A.M., 2008. Effect of chemotherapy with praziquantel on the production of cytokines and morbidity associated with schistosomiasis mansoni. Antimicrob Agents Chemother. 52(8):2780-2786.

Naik SR, Thakare VN, Patil SR., 2011. Protective effect of curcumin on experimentally induced inflammation, hepatotoxicity and cardiotoxicity in rats: evidence of its antioxidant property. Exp Toxicol Pathol. Jul;63[5]:419-31.

Pérez del Villar L, Burguillo FJ, López-Abán J, Muro A., 2012. Systematic review and metaanalysis of artemisinin based therapies for the treatment and prevention of schistosomiasis. PLOS One. ;7[9]:458-67.

Peters PA, Warren KS., 1969. A rapid method of infecting mice and other laboratory animals with Schistosoma mansoni: subcutaneous injection. J Parasitol. 55(3):558-71.

Pellegrino J, Oliveira CA, Faria J, Cunha AS., 1962. New approach to the screening of drugs in experimental schistosomiasis mansoni in mice. Am J Trop Med Hyg. Mar;11:201-15.

Rollinson D, Knopp S, Levitz S, Stothard JR, Tchuem Tchuenté LA, Garba A, Mohammed KA, Schur N, Person B, Colley DG, Utzinger J., 2013. Time to set the agenda for schistosomiasis elimination. Acta Trop. Nov;128[2]:423-40.

Rabia I, Nagy F, Aly E, Mohamed A, EL- Assal F, 
El- Amir A., 2010. Effect of treatment with antifibrotic drugs in combination with $P Z Q$ in immunized Schistosoma mansoni infected murine model. Int J Infect Dis Abstracts, 4th DICID; S16.

Reitman S, Frankel S., 1957. A colorimetric method for the determination of serum glutamic oxalacetic and glutamic pyruvic transaminases. Am J Clin Pathol. Jul;28[1]:56-63.

Sun Y, Chen D, Pan Y, Qu W, Hao H, Wang X, Liu Z, Xie S., 2019. Nanoparticles for antiparasitic drug delivery. Drug Deliv. Dec;26[1]:1206-1221

Sanin DE, Prendergast CT, Bourke CD, Mountford AP., 2015. Helminth Infection and Commensal Microbiota Drive Early IL-10 Production in the Skin by CD4+ T Cells That Are Functionally Suppressive. PLoS Pathog. May 14;11[5]:1048-57.

Santos J, Gouveia MJ, Vale N, Delgado Mde L, Gonçalves A, da Silva JM, Oliveira C, Xavier P, Gomes P, Santos LL, Lopes C, Barros A, Rinaldi G, Brindley PJ, da Costa JM, Sousa M, Botelho
MC., 2014. Urinary estrogen metabolites and selfreported infertility in women infected with Schistosoma haematobium. PLoS One. May 21;9[5]: 967-74.

Silva LM, Oliveira SA, Ribeiro-dos-Santos R, Andrade ZA, Soares MB., 2004. Comparison of immune responses of Schistosoma mansoniinfected mice with distinct chronic forms of the disease. Acta Trop. Jul;91[2]:189-96.

Tendler, M, Pinto, RM, Oliveira, LA, Gebara, G, Katz, N., 1986. Schistosoma mansoni: Vaccination with adult worm antigens. Int. J. Parasitol 16, 4:347-52.

Von Lichtenberg E.V., 1962. Host response to eggs of Schistosoma mansoni Granuloma formation in the unsensitized laboratory mouse, in American Journal of Pathology, 41: 711-731.

Yah CS, Simate GS., 2015. Nanoparticles as potential new generation broad spectrum antimicrobial agents. Daru. Sep 2;23-43.

\section{الملخص العزبي}

تقييم تأثير البرازيكوانتيل المحمل على الجزيئات النانوية PLGA في علاج فئران التجارب المصابة بمرض البلهارسيا المعوية (المنسونية).

جمال على أبو شيعيشع ا"، مصطفى الثحات مصطفى ا"**, إبراهيم علي شلش r, رباب حمد؟.

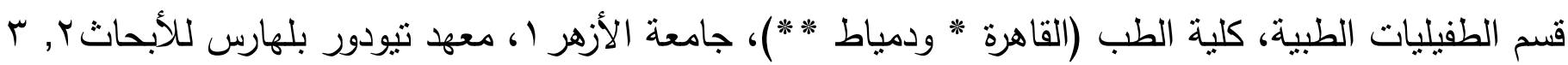

، إمبابة ، الجيزة، مصر ، قسم العلوم البيولوجية، جامعة الملك فيصل س، المملكة العربية السعودية.

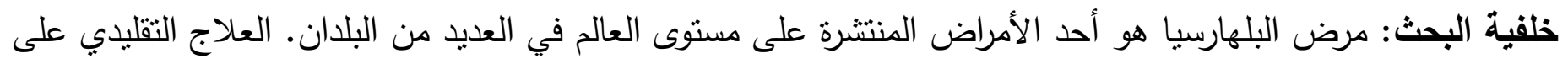
الرغم من فعاليته إلا أن له العديد من العيوب. وبما أنه يوجد هناك اهتمام حديث بالجزيئات النانوية كوسيلة لزيادة فعالية

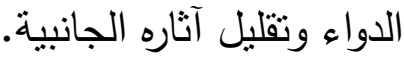


هدف الدراسة: تقييم تأثثر البرازيكوانتيل المحمل على الجزيئات النانوية مقارنة مع البرازيكوانتيل غير المحمل في علاج

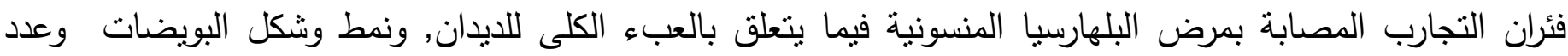

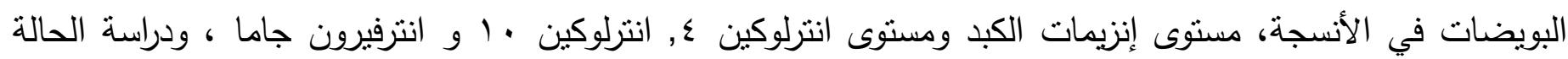
المرضية لأنسجة الكبد عن طريق تحديد عدد الأورام الحبيبية وقياس قطرها.

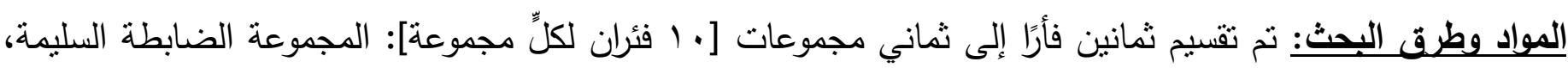

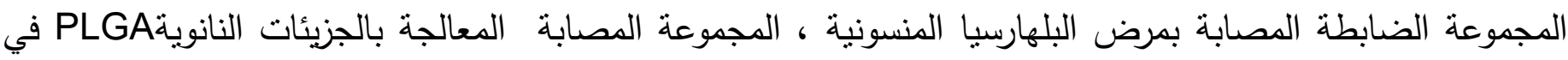

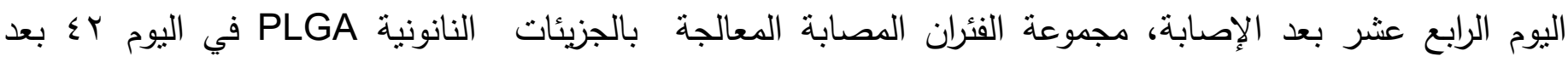
الإصابة، مجموعة الفئران المصابة المعالجة بالبرازيكوانتيل في اليوم الرابع عثر بعد الإصعابة ، مجموعة الفئران المصابة

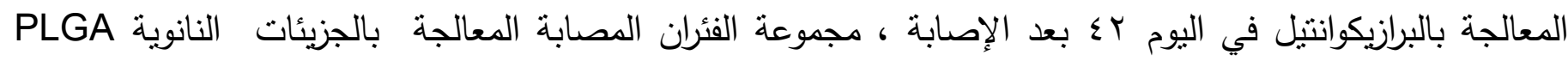

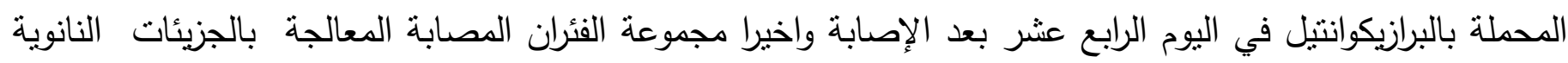

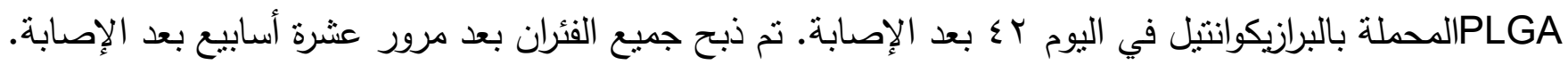

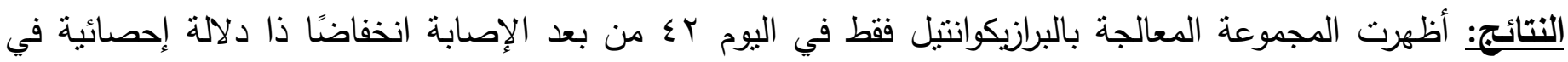

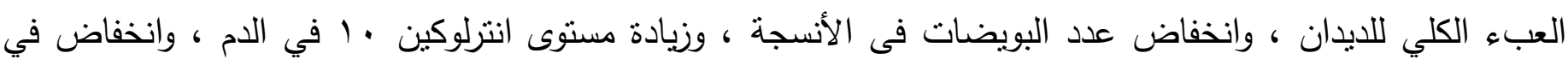
مستويات انزيم AST ، وانزيم ALT ، و انترلوكين ؛ ، و و انترفيرون جاما وانخفاض متوسط قطر وعدد الأورام الحبيبية

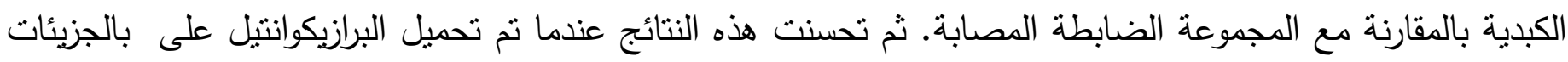

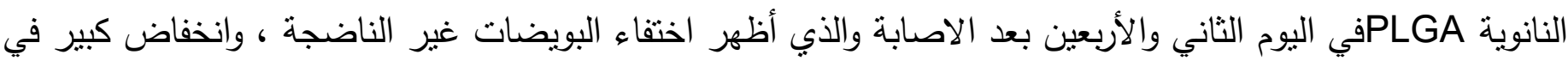

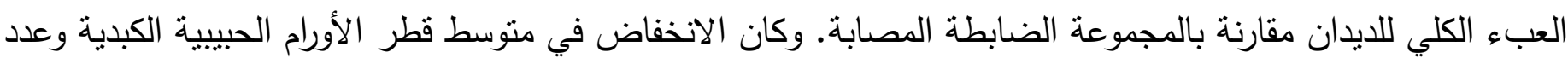

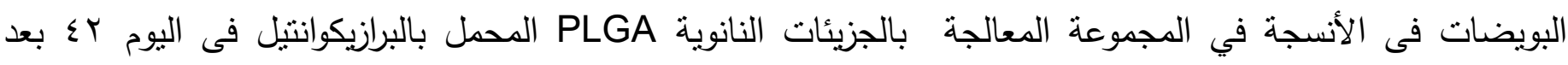

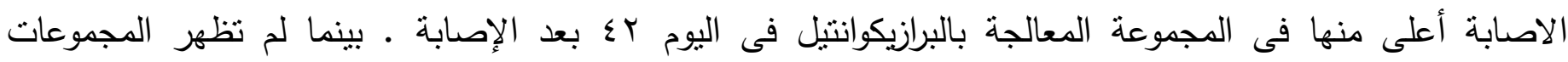

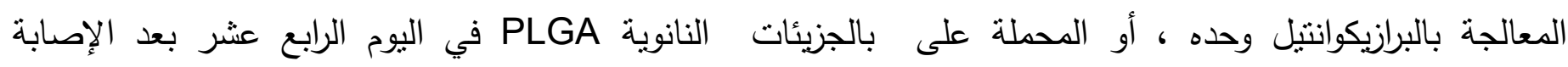

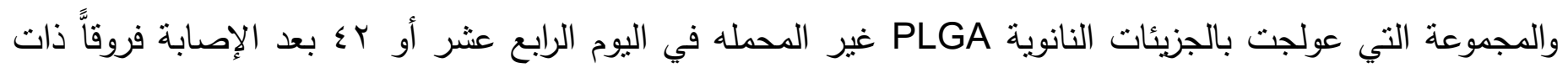
دلالة احصائية فيما يتعلق بعبء الدودة الكلي ، وعدد البويضات فى الأنسجة ، ومتوسط قطر الأورام الحبييية الكبدية وعددها ومستويات AST و ALT و انترلوكين ؛ وانترلوكين • ( مقارنة بالمجموعة الضابطة المصابة.

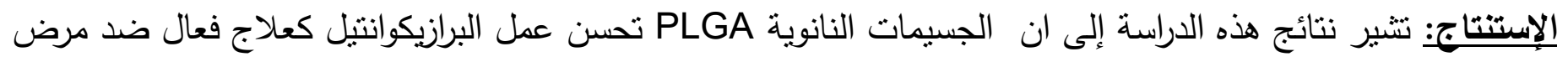
البلهارسيا فى الفئران فيما يتعلق بجميع المعايير التي نم تقييمها ، لا سيما الإنخفاض الكبير في متوسط قطر الأورام

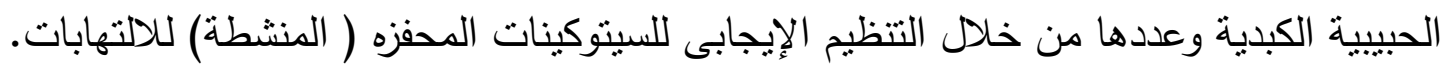

